\title{
Hunting and trapping in Lebialem Division, Cameroon: bushmeat harvesting practices and human reliance
}

\author{
Juliet H. Wright*, Nancy E. C. Priston \\ Department of Anthropology and Geography, School of Social Sciences and Law, Oxford Brookes University, \\ Gipsy Lane, Oxford OX3 0BP, UK
}

\begin{abstract}
Bushmeat hunting has evolved into a large-scale commercial activity in western and central Africa. Primates are particularly vulnerable to over-exploitation and tend to be absent from heavily hunted areas. To reduce their rate of decline, human use of, and reliance on, bushmeat must be understood so that locally appropriate mitigation strategies can be developed. We address the social dimension of bushmeat hunting by revealing why people hunt, the techniques used, harvest composition, species preferences and the nature of human economic and nutritional reliance. Data were collected during May and June 2007 in Lebialem Division, Southwest Region, Cameroon. Ninety semi-structured interviews with hunters and trappers were conducted alongside participatory appraisal sessions in 6 rural communities. The main reason for harvesting bushmeat was income generation. Shotguns were the weapon of choice, enabling $74 \%$ of interviewees to hunt primates. A decrease in mammalian abundance was reported by $88 \%$, motivating hunters to trek to protected areas outside of Lebialem. $64 \%$ sold more bushmeat than they consumed, with hunters selling a greater proportion than trappers, due to species composition. Fish was the principle source of animal protein consumed on a regular basis. Hunting and trapping were mainly secondary incomegenerating activities, but the flexibility of labour inputs and rates of return make them important livelihood components. To reduce financial reliance on bushmeat harvesting and the volume of species extracted, the development of economic alternatives and conservation education programmes should be given priority.
\end{abstract}

KEY WORDS: Bushmeat · Southwest Cameroon $\cdot$ Livelihoods · Primates $\cdot$ Hunting behaviour Resale or republication not permitted without written consent of the publisher

\section{INTRODUCTION}

The Guineo-Congolian forests of western and central Africa are currently experiencing a 'boom' in bushmeat hunting (Barnes 2002). This traditional practice has evolved into a large-scale commercial activity due to rapid human population growth, socioeconomic change, infrastructure development and technological improvements (Bennett \& Robinson 2000). A wide variety of terrestrial vertebrates are consumed as bushmeat, with ungulates, rodents and primates constituting the majority ( $\mathrm{Fa}$ et al. 2005). Estimates for bushmeat consumption across the

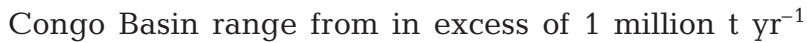

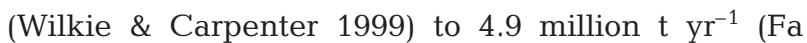
et al. 2002).

The current level of harvesting is deemed unsustainable; estimates suggest wildlife extraction is occurring at more than 6 times the sustainable rate (Robinson \& Bennett 2000, Bennett 2002). Medium to large-bodied species with slow reproductive rates, including many species of primate, are particularly vulnerable to overexploitation (Fa et al. 2005, Nasi et al. 2008). Studies have found primates to be absent from, or at very low densities in, heavily hunted areas (Oates et al. 2000, Peres 2000, Maisels et al. 2001, Isaac \& Cowlishaw 2004). Lebialem in southwest Cameroon contains some of Africa's most threatened primate species, including 
the Cross River gorilla Gorilla gorilla diehli, NigeriaCameroon chimpanzee Pan troglodytes vellerosus, drill Mandrillus leucophaeus and Preuss's guenon Cercopithecus preussi (Ekinde \& Khumbah 2006, Nkembi et al. 2006, IUCN 2009).

Research has focused primarily on providing theoretical and analytical tools to ascertain the extent of the commercial trade, identify vulnerable species and estimate sustainable limits to human exploitation (Robinson \& Redford 1994, Bowen-Jones \& Pendry 1999, Fa et al. 2006). However, social factors will ultimately determine the success or failure of conservation initiatives designed to mitigate this complex, multifaceted problem (Mascia et al. 2003). It is feared that 'the bushmeat crisis' will lead to species extinctions and subsequent food shortages among dependent human populations (Fa et al. 2003). Determining the importance of bushmeat to human livelihoods is necessary if solutions that further both conservation and development objectives are to be implemented.

The social dimension of bushmeat has received increased academic attention over recent years (Bennett 2002, Brown \& Williams 2003, Bennett et al. 2007, Nasi et al. 2008), but there have been relatively few empirical studies about the role of bushmeat in livelihoods (de Merode et al. 2004, Kümpel 2006, Willcox \& Nambu 2007). As social situations differ between areas, it is important to explore regional variation by increasing the number of case studies. Research is particularly needed in areas affected by conservation policies so that mitigation strategies can be tailored to local circumstances.

We address the social dimension of bushmeat in Lebialem by examining it from the perspective of the hunter. Qualitative methods were employed in order to explore the social factors underlying bushmeat hunting in 6 rural communities. The objectives were to (1) reveal reasons for harvesting bushmeat, (2) describe harvesting behaviour, (3) identify species harvested and preferences, and (4) determine economic and nutritional reliance. A comparison is made between the communities to identify which factors influence hunting behaviour. The nature of human reliance on bushmeat is discussed in order to direct conservation action.

\section{MATERIALS AND METHODS}

Study site. Lebialem Division is located in the Southwest Region of Cameroon (Fig. 1). It encompasses $617 \mathrm{~km}^{2}$ of mountains with an altitudinal range of 200 to $2350 \mathrm{~m}$ (Institut National de la Statistique 2006). Semi-evergreen tropical broadleaf forest dominates the lower altitudes (International Tropical Timber Organization 2006). Lebialem contains 2 main for- est blocks, Mbin-mak forest and the Bechati-Fossimondi-Besali (BFB) forest. It is bordered by BanyangMbo Wildlife Sanctuary (BMWS) to the southwest, but none of the forest within Lebialem has any legal protection status. A Cameroonian NGO, the Environment and Rural Development Foundation (ERuDeF), has been operating in the area since 1999, focusing on Cross River gorilla surveys. The rainy season lasts from mid-March to the end of October, with August being the wettest month and February being the driest. Annual rainfall in the area ranges from 3438 to 5429 mm with a mean of $4526 \mathrm{~mm}$ (Nchanji 2005).

The most recent population estimate for Lebialem was 144560 in 2001, and the national population growth rate is $2.2 \%$ (Institut National de la Statistique 2006, CIA 2008). Lebialem contains 3 subdivisions: Fontem, Alou and Wabane. Menji ( $\left.5^{\circ} 28^{\prime} \mathrm{N}, 9^{\circ} 53^{\prime} \mathrm{E}\right)$ is the divisional headquarters and the main commercial centre. The 3 subdivisions are further divided into 17 traditional kingdoms, known as fondoms. Fondoms are divided into quarters. Christianity is the prominent religion in the area, which tends to be practised alongside traditional religious belief systems (Mbaku 2005). The Mundani and Bangwa ethnic groups predominate, with the Mundani occupying Wabane subdivision while the Bangwa occupy Alou and Fontem subdivisions. A third group, the M'muock, occupy 3 fondoms within Alou subdivision. The economy of Lebialem is dominated by agriculture. The main cash crops are oil palm, cocoa, coffee and potatoes, with surplus subsistence crops also being traded. Few opportunities exist for paid employment within the division (J. H. Wright pers. obs.).

Data collection. Data were collected over an $8 \mathrm{wk}$ period in May and June 2007. Six rural communities were selected: 5 typical forest-adjacent villages (Andu,

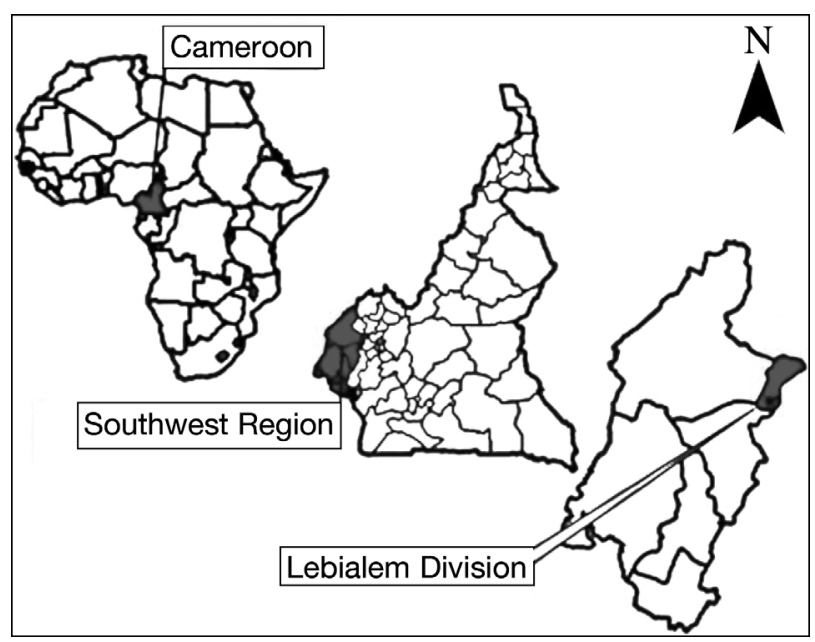

Fig. 1. Location of Lebialem Division, Southwest Region and Cameroon within Africa (adapted from Etiendem 2008) 
Atongeh, Bechati, Besali, Fossimondi) and the town of Menji (Fig. 2). Bushmeat hunting is prevalent in all forest-adjacent communities in this region. Research communities, henceforth collectively referred to as 'villages,' were either defined at the fondom level or at the quarter level depending on the autonomy of the settlement and degree of isolation from neighbouring settlements. Villages adjacent to both forest blocks were selected; all ethnic groups are represented through this selection, and the communities are at the local extremes of accessible and inaccessible with regards to motorised transportation (Table 1). Selecting villages adjacent to both forest blocks was deemed necessary to assess how hunting behaviour is affected by resource availability. Collecting data from members

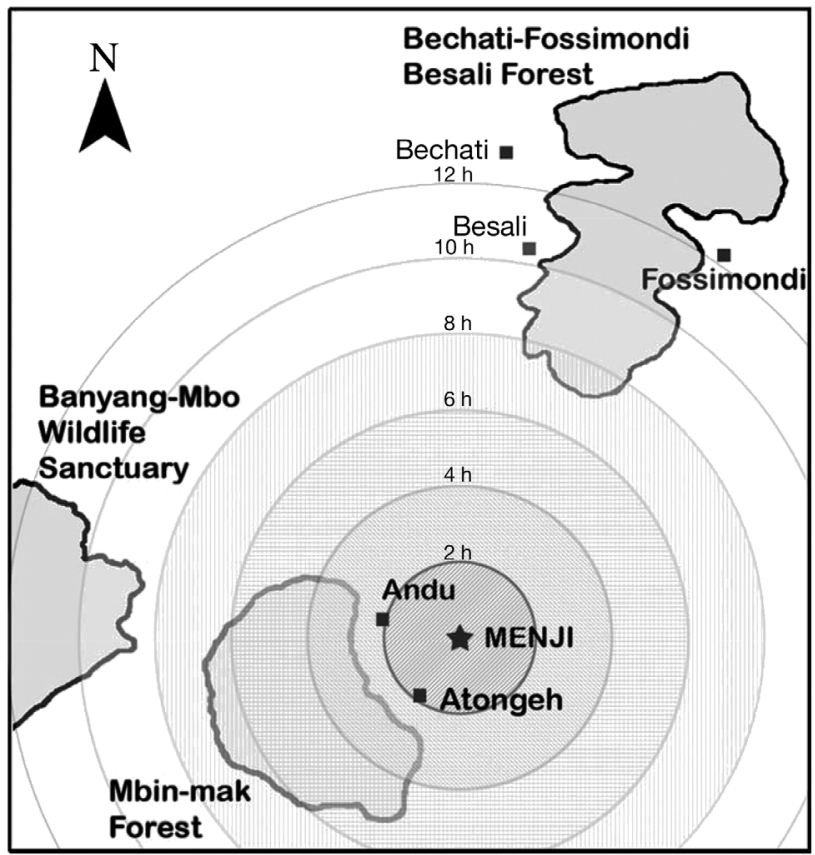

Fig. 2. Map of the 6 study villages and 3 forest blocks, indicating trekking times (h) from Menji

Table 1. Population, ethnicity and accessibility of the 6 study villages in Lebialem Division and their classification in the divisional system. Est: estimate

\begin{tabular}{|c|c|c|c|c|}
\hline Village & Subdivision & Population & Ethnicity & Road access \\
\hline $\mathrm{Andu}^{\mathrm{a}}$ & Fontem & 200 (est.) & Bangwa & No \\
\hline Atongeh $^{a}$ & Fontem & 200 (est.) & Bangwa & No \\
\hline Bechati & Wabane & $3408^{b}$ & Mundani & Seasonal $^{\mathrm{C}}$ \\
\hline Besali & Wabane & $3980^{\mathrm{b}}$ & Mundani & Seasonal $^{\mathrm{C}}$ \\
\hline Fossimondi & Alou & $8900^{\mathrm{b}}$ & M'muock & Seasonal $^{\mathrm{C}}$ \\
\hline Menji $^{\mathrm{a}}$ & Fontem & 13000 (est.) & Bangwa & Yes \\
\hline
\end{tabular}

of all 3 ethnic groups was considered important to determine whether ethnicity has an influence on hunting behaviour and species harvested. Finally, villages with varying degrees of accessibility were chosen in order to study the effect this variable has on reliance.

The research team consisted of 1 researcher $(\mathrm{J} . \mathrm{H}$. W.) and 2 local assistants who were graduates familiar with the study villages and research protocols. The assistants acted as facilitators and translators to increase rapport between the researcher and the communities. The length of time spent in each village ranged from 4 to $15 \mathrm{~d}$ depending on population size. The research team lived with hunters and their families during this period to gain an appreciation of their way of life. J. H. W. has visited the area on 2 other occasions since this initial data collection period and has now spent in excess of 5 mo living with hunters in Lebialem.

We used interviews and participatory appraisal techniques to obtain the necessary data for this investigation. A semi-structured interviewing approach was adopted to guide respondents through key themes whilst tailoring each interview to the knowledge and experience of the interviewee (O'Reilly 2005). Interviews were conducted with 2 actor groups, hunters and trappers. The term 'hunter' is used henceforth to refer to those who actively search the forest for prey, whereas 'trapper' refers to those who set snares and passively wait for animals to enter them. This distinction has been made in line with how the people define themselves. Participants were recruited using a snowballing technique (Cowlishaw et al. 2005b). Hunters, trappers, traders and other villagers identified individuals involved in the bushmeat harvest. In total, 90 harvesters were interviewed: 68 hunters and 22 trappers. The number of interviewees per village ranged from 10 to 27 .

The majority of interviews were conducted in English or pidgin English. Each interview began with a series of structured questions to obtain quantitative demographic variables for every participant. Twenty-seven questions were used as prompts during the remainder of the interview (see Appendix 1). Themes covered were (1) reasons for harvesting bushmeat, (2) harvesting behaviour, (3) harvest composition, (4) income sources, and (5) diet. Participatory appraisal exercises were conducted with a group of 6 to 18 harvesters in each village. Participants produced maps to identify harvesting areas and ranks to ascertain preferences and relative frequencies (Rietbergen-McCracken \& Narayan 1998). 
Bushmeat species were ranked according to profit, taste, frequency of catch, abundance in the forest and importance as a food and income source.

To enable the identification of harvested animals, photographs of species previously recorded as bushmeat in the vicinity (Fa et al. 2006, Willcox \& Nambu 2007) and in the surrounding forest (Sanderson 1940, Ekinde \& Khumbah 2006, Nkembi et al. 2006, Forboseh et al. 2007) were presented to interviewees on laminated sheets. Species absent from these sheets were identified using Kingdon (1997). When discrepancies occurred, a description of the animal was taken and it was later identified as accurately as possible at the level of species, genus, family or suborder. Overt observations of bushmeat further verified species identification. For species undergoing taxonomic reclassification, the scientific names given by the IUCN (2009) have been used.

Data analysis. Qualitative interview data were analysed using a textual approach focusing on words and meanings (Dey 1993). Responses were thematically grouped and within each group the data were categorised. Qualitative categories were eventually quantified and input as nominal or ordinal data into SPSS version 13, along with quantitative demographic variables for each respondent. Basic frequencies were calculated for all categorical data and appropriate charts produced. Further analysis using crosstabulations and clustered bar graphs was conducted in an attempt to identify confounding variables. Continuous data were analysed in SPSS or Microsoft Excel and descriptive statistics calculated. The nonparametric Kruskal-Wallis test was used to determine the significance of differences between villages and the Mann-Whitney $U$-test was used to investigate differences between hunters and trappers. Differences between nominal variables were tested using chisquared and the likelihood ratio (Field 2005). Significance was set at $\mathrm{p}<0.05$.

Taste ranks were calculated from data generated during interviews by assigning a score to each species listed by each respondent in order of preference. The species considered tastiest were allocated 5 points and the species listed fifth were allocated 1 point. The total score for each species was calculated, as were the subtotals for each village. A similar approach was used to incorporate the ranks from the participatory appraisal exercises conducted in each village into an overall hierarchy. Associations between ranked and other scale variables were correlated using Spearman's correlation coefficient (Gravetter \& Wallnau 2000). In order to investigate what determined species price, mean selling prices were calculated using respondent estimates, and weight data was taken from Kingdon (1997).

\section{RESULTS}

\section{Reasons for bushmeat harvesting}

Bushmeat harvesters $(\mathrm{n}=90)$ were exclusively male with a median age of $42 \mathrm{yr}$ (inter-quartile range, IQR = 22). There was little variation between the median age of hunters (42.0 yr) and trappers (43.5 yr). Income generation was the reason for harvesting that was stated most frequently during interviews (46\%). A typical response would be: 'hunting is the only way of getting immediate cash.' Providing food for themselves and their families was the second most common response $(33 \%)$, followed by tradition (18\%) and pest control $(3 \%)$. Tradition has become less influential in terms of encouraging people to hunt, as all those who started over the last 5 yr began independent of family connections. The reasons for involvement differed significantly between the 6 communities (likelihood ratio: L $\chi^{2}$ $=28.276, \mathrm{df}=15, \mathrm{p}=0.02)$. Whilst income generation predominated in 4 communities, Bechati and Besali were notable exceptions, giving mainly subsistence reasons for harvesting (Fig. 3).

\section{Harvesting behaviour}

The most common form of bushmeat harvesting in Lebialem is with shotguns $(72 \%)$, which are manufactured locally and can be bought for 10000 to 15000 FCFA (US \$20.57 to 30.86) (P. Nkwetta, pers. comm.). Three of the hunters $(n=68)$ used dogs instead of guns and 8 used dogs as well as guns, bringing the percentage of dog users to $16 \%$. Dogs are used to locate prey, chase animals into positions which make them easier to shoot and fetch animals once shot. Hunters said they spent a median number of $12 \mathrm{~d} \mathrm{mo}^{-1}$ in the forest (IQR $=8$ ). This average could reflect hunting practices during the rainy season when the study was conducted. Hunting is conducted throughout the year, but preference was shown for the dry season months of November and December. However, the agricultural cycle, rather than climatic conditions, appears to dictate periods of intensive hunting.

Fifty-three percent of hunters also set traps, bringing the total number of trappers interviewed to 58. Handtwisted wire snares were used by $90 \%$ of trappers. Alternatives included locally produced 'mousetrap' style devices $(350 \times 180 \mathrm{~mm})$, iron traps and pit-fall traps. Wire snares were preferred because a bundle of wire, which can produce up to 100 snares, costs between 2500 to 3500 FCFA (US \$5.15 to 7.21). In comparison, 'mousetrap' style devices cost 500 FCFA (US \$1.03) each and iron traps cost 5000 FCFA (US $\$ 10.30)$ each. The number of snares respondents 


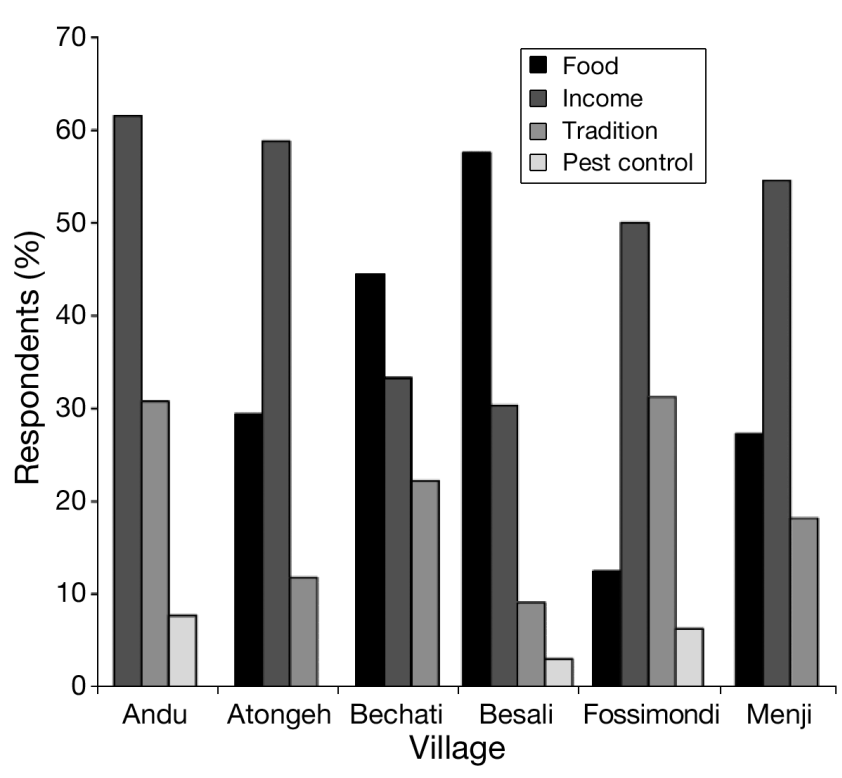

Fig. 3. Reasons for bushmeat harvesting in the 6 study villages expressed as percentage of respondents from each village

claimed to set annually ranged from 14 to 500, with a median of 120 per trapper. Trappers said they spent a median number of $12 \mathrm{~d} \mathrm{mo}^{-1}$ in the forest $(\mathrm{IQR}=5)$. Respondents (86\%) preferred to trap during the rainy season when the ground was soft enough for vegetation manipulation.

Bushmeat harvesters have unrestricted access to both Mbin-mak forest and the BFB forest. Respondents from Bechati, Besali and Fossimondi only harvested bushmeat from the BFB forest. The majority of respondents from Andu $(85 \%, \mathrm{n}=13)$ and Atongeh $(71 \%, \mathrm{n}=14)$ harvested from their closest forest, Mbin-mak. However, 2 hunters from Andu and 3 from Atongeh said they regularly walked for 7 to $11 \mathrm{~h}$ to BMWS. The majority from Menji $(70 \%, \mathrm{n}=10)$ also made this journey, due to the lack of forest and prey species in their vicinity. One hunter from Atongeh opted to hunt in the BFB forest. The notable differences between the 3 forest blocks are the known presence of Cross River gorillas in the BFB forest and the protected status of BMWS (Ekinde \& Khumbah 2006, Bergl et al. 2007).

\section{Harvest composition}

The species most respondents claimed to harvest are listed in descending order of frequency (Table 2). All the prey species listed are mammals, with rodents, ungulates and primates predominating. The African brush-tailed porcupine Atherurus africanus was said to be harvested by $96 \%$ of all those interviewed and was consistently listed by the most respondents in each village. Seventy-four percent of interviewees said they harvested primates. This proportion did not differ significantly between villages (Kruskal-Wallis: $H=5.923$, $\mathrm{df}=5, \mathrm{p}=0.314$ ).

Guenons Cercopithecus erythrotis, C. mona, C. nictitans, and C. preussi were predominately hunted using shotguns, but occasionally fall victim to traps. Drills were reported to be scarce and could only be located by those hunting with dogs. Nocturnal prosimians Galago spp. and Perodicticus potto are reportedly harvested by hand during the day or shot by hunters at night. Twenty-four percent of hunters had shot at least 1 chimpanzee or gorilla. Great apes were hunted using shotguns but the risk to personal safety was a deterrent for some individuals $(\mathrm{n}=13)$.

Table 2. Harvest rank of the 10 species or groups of species hunted and trapped by the most respondents (n = 90) listed in descending order. Species are grouped if vernacular names referred to more than one species. The mean price \pm SD for each species is listed. The rank and prices are based on interview responses rather than carcass counts but provide an indication of harvest composition and of selling price in FCFA (1000 FCFA = US \$2.06 as of 30 June 2007). $\mathrm{n}$ in 'Mean price' column: no. of respondents who provided a price estimate

\begin{tabular}{|c|c|c|c|c|}
\hline \multicolumn{2}{|r|}{ Species } & \multirow{2}{*}{$\begin{array}{l}\text { English name } \\
\text { African brush-tailed porcupine }\end{array}$} & \multirow{2}{*}{$\begin{array}{l}\text { Vernacular name } \\
\text { Chugger-chugger }\end{array}$} & \multirow{2}{*}{$\begin{array}{c}\text { Mean price }( \pm \mathrm{SD}) \\
\text { in FCFA } \\
3855 \pm 990(\mathrm{n}=67)\end{array}$} \\
\hline 1 & Atherurus africanus $(\mathrm{n}=86)$ & & & \\
\hline 2 & Cercopithecus spp. $(\mathrm{n}=58)$ & Guenons & Monkey & $5136 \pm 1440(\mathrm{n}=50)$ \\
\hline 3 & $\begin{array}{l}\text { Cephalophus dorsalis, } \\
\text { C. ogilbyi }(\mathrm{n}=55)\end{array}$ & Bay duiker, Ogilby's duiker ${ }^{a}$ & Red deer & $10846 \pm 3056(n=39)$ \\
\hline 4 & Cephalophus monticola $(\mathrm{n}=51)$ & Blue duiker & Frutambo & $3731 \pm 904(\mathrm{n}=41)$ \\
\hline 5 & Galagidae spp., Perodicticus potto $(n=46)$ & Galagos, potto & Bush baby & $1230 \pm 639(\mathrm{n}=26)$ \\
\hline 6 & Cricetomys emini $(\mathrm{n}=45)$ & Giant pouched rat & Rat mole & $1025 \pm 695(\mathrm{n}=26)$ \\
\hline 7 & Phataginus tricuspis $(\mathrm{n}=40)$ & Tree pangolin & Cutter beef & $2599 \pm 676(n=25)$ \\
\hline 8 & Thryonomys swinderianus $(\mathrm{n}=38)$ & Greater cane rat & Cutting grass & $4282 \pm 1657(\mathrm{n}=29)$ \\
\hline 9 & Potamochoerus porcus $(\mathrm{n}=28)$ & Red river hog & Bush pig & $37600 \pm 13263(\mathrm{n}=17)$ \\
\hline 10 & Mandrillus leucophaeus $(\mathrm{n}=25)$ & Drill & Sumbo & $15889 \pm 7871(\mathrm{n}=16)$ \\
\hline
\end{tabular}




\section{Species preferences}

African brush-tailed porcupine was undoubtedly the preferred species in Lebialem in terms of taste (Table 3). It came at the top of every village taste rank. Guenons ranked second overall but were preferred in the Mundani villages of Bechati and Besali. Taste positively correlated with species harvested (Spearman: $\mathrm{r}_{\mathrm{s}}$ $=0.845, \mathrm{n}=19, \mathrm{p}<0.001$ ) (Fig. 4). Price was said to be primarily determined by the weight of the animal $(76 \%, \mathrm{n}=56)$. Mean price positively correlated with mean weight (Spearman: $r_{S}=0.912, n=19, p<0.001$ ). A tendency suggests that taste may also be positively correlated with mean price $\left(\mathrm{r}_{\mathrm{S}}=0.431, \mathrm{n}=19, \mathrm{p}=\right.$ 0.066). No significant correlation was found between mean price and species harvested (Spearman: $\mathrm{r}_{\mathrm{S}}=$ $0.076, \mathrm{n}=24, \mathrm{p}=0.723$ ) (Table 2). Eighty-eight percent of informants $(n=82)$ reported a decrease in mammalian abundance over the period of time they had been harvesting bushmeat. As profitable large-bodied species have become rarer, the ability of bushmeat harvesters to target these species appears to have reduced. Seventy percent of the respondents $(n=10)$ that had not noticed a change in prey abundance harvested from the BFB forest.

Each interviewee was encouraged to share information about traditional beliefs regarding local species. Twenty-six percent of respondents discussed the transformation phenomena, a belief that certain people can transform into animals. This belief appears to be widespread throughout Lebialem and was held by members of all ethnic groups. It was mentioned by more than $30 \%$ of interviewees in all villages except Fossimondi and Menji. Chimpanzees and gorillas were the main focus of these discussions, although the leopard Panthera pardus, African forest buffalo Syncerus caffer nanus, forest elephant Loxodonta cyclotis and python Python sebae were also thought to be people in dis-

Table 3. Taste preference rank of bushmeat species combining data from interviews and participatory appraisal sessions with bushmeat harvesters $(n=90)$. Score: sum of all interviewee ratings, on a scale of 1 to 5

\begin{tabular}{|llc|}
\hline Rank & Species & Score \\
\hline 1 & African brush-tailed porcupine & 397 \\
2 & Guenons & 152 \\
3 & Tree pangolin & 96 \\
4 & Greater cane rat & 82 \\
5 & Red duikers & 58 \\
6 & Giant pouched rat & 50 \\
7 & Blue duiker & 45 \\
8 & Red river hog & 44 \\
9 & Guinea fowl (Guttera spp.) & 43 \\
10 & Water chevrotain (Hyemoschus aquaticus) & 39 \\
\hline
\end{tabular}

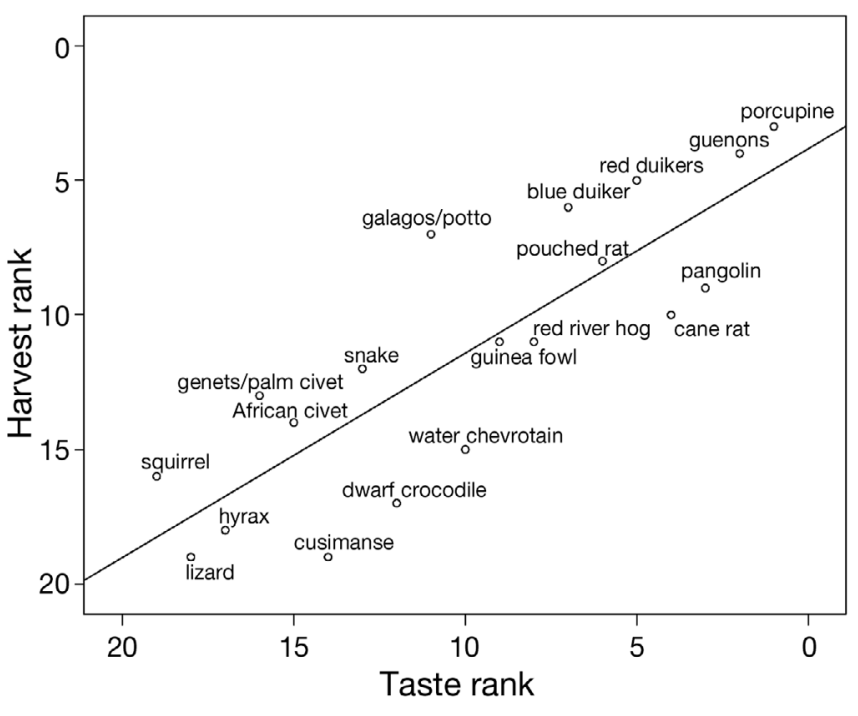

Fig. 4. Relationship between harvest rank and taste rank for 19 bushmeat species or groups of species $(1=$ most harvested or tasty and 19 = least harvested or tasty). Only species that could be ranked in terms of harvest and taste were included in this analysis. Species not otherwise mentioned in the present study: African civet Civettictis civetta, flat-headed cusimanse Crossarchus platycephalus, genets Genetta spp., African palm civet Nandinia binotata, western tree hyrax Dendrohyrax dorsalis, squirrels Sciuridae spp., dwarf crocodile Osteolaemus tetraspis, lizards Lacertilia spp., snakes Serpentes spp.

guise. Attitudes towards this form of witchcraft were positive. Eighty-three percent of those that believed in transformation $(n=23)$ said they did not shoot apes for fear of killing a person. However, not all believers avoided hunting apes. Traditional beliefs regarding wildlife appear to be losing their supporters and enforcers.

\section{Sources of income and protein}

Whilst $33 \%$ of respondents said they earned the majority of their income from bushmeat harvesting activities, farming was stated as the primary occupation for $58 \%$ of interviewees (Fig. 5). Hunting and trapping appear to be mainly secondary incomegenerating activities. In $46 \%$ of cases, the money earned from trapping actually ranked third or fourth when compared with the individuals' other sources of income. Ratios were calculated to reflect the proportion of bushmeat harvests reported to be sold and consumed by each respondent. Sixty-four percent sold more than they consumed. Hunters sell a greater proportion of their catch when compared to trappers (Mann-Whitney: $Z=-1.993, \mathrm{n}=88, \mathrm{p}=0.046$ ). No significant difference was found in the proportion of 


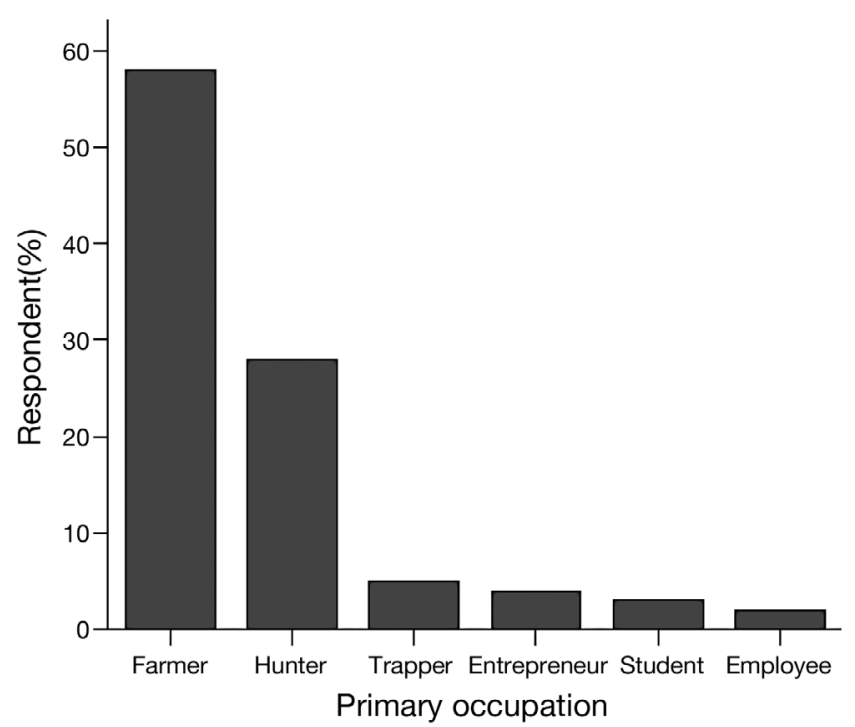

Fig. 5. Primary occupation of respondents $(n=90)$, defined as the activity that earns the greatest income

bushmeat sold and consumed between the 6 villages (Kruskal-Wallis: $H=6.488, \mathrm{df}=5, \mathrm{p}=0.262$ ). However, on average, Bechati and Besali harvesters sold 6 carcasses for every 4 consumed, whereas harvesters from the remaining villages sold 7 carcasses for every 3 consumed.

The sources of protein available in Lebialem include bushmeat, domestic meat (beef, pork, goat and poultry), fish and other aquatic organisms, eggs and vegetable proteins. Due to the lack of electricity in all of the villages except Menji, meats are sold fresh or smoked rather than frozen. Fish was the cheapest source of protein available and featured prominently in the diet of bushmeat harvesters. Eighty percent said they consumed it on a weekly basis, with most (53\%) eating it on 1 or $2 \mathrm{~d} \mathrm{wk}^{-1}$. While some of the fish originates from coastal towns $175 \mathrm{~km}$ to the southwest, the majority is freshwater fish harvested from local rivers. Although fewer respondents $(70 \%)$ said they ate bushmeat on a weekly basis, $55 \%$ of those consumed it on more than $3 \mathrm{~d} \mathrm{wk}^{-1}$, making bushmeat the meat most frequently eaten by hunters and trappers.

Domestic meat was said to be consumed at least once a week by $52 \%$ of respondents but was rarely eaten on more than 1 or $2 \mathrm{~d}$. Pigs, goats and poultry were kept by residents in all villages but are eaten only during ceremonial occasions and tend to be viewed as savings rather than food. The majority of domestic meat for consumption is brought into Lebialem by traders and sold at the weekly markets (D. Etiendem, pers. comm.). When bushmeat consumption was correlated with fish consumption, a significant negative association be- came apparent (Spearman: $\mathrm{r}_{\mathrm{S}}=-0.279, \mathrm{n}=77, \mathrm{p}=$ $0.014)$. No such association was found between bushmeat and domestic meat consumption (Spearman: $\mathrm{r}_{\mathrm{S}}=$ $-0.063, \mathrm{n}=77, \mathrm{p}=0.583$ ).

\section{DISCUSSION}

Caution is needed when interpreting data from interviews and participatory appraisal exercises. The motivations of respondents must be considered. Although the forests of Lebialem are not legally protected, several species that inhabit the area are protected to varying degrees by Law No.94/01 of 20 January 1994 (Djeukam 2004). Local assistants helped to gain the trust of participants, but fear of restrictions may still have influenced some responses. A desire to benefit from external assistance may also have affected participant answers; however the fact that the researcher was a student unaffiliated with any international conservation or development organisations was emphasised. Data were collected for a relatively short period during the rainy season and this should be taken into consideration before generalising the results. Observations and discussions during further visits to Lebialem confirm the general assertions that have been made.

There is a marked division of labour within the bushmeat industry in Lebialem, with all hunters and trappers being male. This has been noted in all areas studied in west and central Africa (Fa 2007). Women are also actively involved in the bushmeat trade, but as wholesalers and sellers (Mendelson et al. 2003, Solly 2004, J. H. Wright pers. obs.). The majority of bushmeat harvesters were aged between 30 and 52. This age group is likely to have growing families and greater responsibilities, making them more prone to resort to bushmeat harvesting as a means of feeding and providing income for the household. Younger males often leave their village to find employment elsewhere.

In the literature, snares are often referred to as the principle weapon used for bushmeat harvesting throughout afrotropical forests (Fa et al. 2005, Kümpel 2006). Evidence from recent studies contradicts this generalisation. In northeast Gabon, van Vliet \& Nasi (2008) reported that trapping was an activity only conducted by males over $45 \mathrm{yr}$ and that shotguns were used during $85 \%$ of recorded hunting trips. Whereas $15 \mathrm{yr}$ ago, snares were more commonly used in this area than guns (Lahm 1993, cited in van Vliet \& Nasi 2008). There was no age-related distinction between hunters and trappers in Lebialem, but shotguns were the weapon of choice for the majority of respondents. This was also noted in a study of the neighbouring 
Banyangi and Mbo tribes who live in and around BMWS (Willcox \& Nambu 2007).

The increasing use of shotguns has implications for primate conservation. Primates are nearly always shot (Fa et al. 2005). The increased use of guns in Gabon has significantly increased hunting pressures on small diurnal monkeys, which are now mainly found more than $10 \mathrm{~km}$ away from villages (van Vliet \& Nasi 2008). Larger-bodied primates are most sought after because they provide a greater return on investment (Oates 1996). Chimpanzees and gorillas were targeted by $24 \%$ of hunters but killed infrequently due to the rarity of encounters. Drill populations have declined dramatically in Korup National Park, southwest Cameroon, since hunters combined the use of guns and dogs (Waltert et al. 2002). Of the respondents in Lebialem $9 \%$ had also adopted this technique to hunt drills, but drill scarcities might explain its current limited use.

Small diurnal monkeys are relatively easy targets for shotgun hunters due to their social organisation. One well-placed cartridge can kill several animals (Muchaal \& Ngandjui 1999). Cercopithecus spp. appear to be the most frequently hunted primates in Lebialem due to their relative abundance. They also accounted for $81 \%$ of the primate carcasses identified during an extensive 5 mo survey of bushmeat markets between the Cross River in Nigeria and the Sanaga River in Cameroon, an area which encompasses Lebialem (Fa et al. 2006). Nocturnal prosimians were often considered too small to be worth the cost of a shotgun cartridge, yet contrary to the assumptions of optimal foraging theory were hunted by $51 \%$ of respondents (Cowlishaw \& Dunbar 2000). When the likelihood of encountering preferred species is low, i.e. on the last day of a hunting trip, hunters will use their ammunition on whatever is available to avoid the unbearable scenario of returning empty-handed.

Fa et al. (2006) reported that ungulates comprised the greatest proportion of carcasses sold (36\%) in the Cameroon section of their survey area, followed by rodents $(34 \%)$ and primates $(20 \%)$. Ungulates, particularly blue duikers, have been reported to constitute the majority of species harvested at a number of study locations (Dja Reserve, Cameroon; Muchaal \& Ngandjui 1999), (Republic of Congo; Eves \& Ruggiero 2000), (Gabon; van Vliet \& Nasi 2008). Calculating the number of respondents claiming to harvest species from the 3 dominant orders suggests that rodents, rather than ungulates, constitute the greatest proportion of the offtake in Lebialem. The dominance of rodents in harvest data has been suggested as an indicator of overexploitation (Cowlishaw et al. 2005a, Fa et al. 2005). In this case, the prominence of rodents in harvest ranks is likely to be a reflection of their relative abundance and the fact they can be targeted by all individuals irrespective of harvesting method.

Economic value is mainly determined by the weight of prey species. Larger species are usually found further away from human habitation, in mature forest (van Vliet \& Nasi 2008). More commercially orientated harvesters tend to travel further into the forest to increase the value of their catch (Coad 2007). When it becomes uneconomical to hunt or trap in a particular forest block, according to the patch departure model of optimal foraging theory, harvesters should move on to more profitable areas (Cowlishaw \& Dunbar, 2000). Thirteen hunters in Lebialem appear to have shifted their activities away from their closest forest, Mbinmak, to BMWS and the BFB forest. This indicates that populations of larger mammals in Mbin-mak have diminished. Reports of declining wildlife by $88 \%$ of respondents suggest that harvesting pressures are having a negative impact on species populations in all 3 forest areas.

Price and taste are characteristics of bushmeat that could affect harvester selectivity. The mean price of each species did not correlate with harvest rank, as would be expected if harvesters were selecting in order to maximise their financial rates of return. However, the tastiest species did tend to be those most harvested. Whilst this could indicate that harvesters select according to taste preferences, it seems likely that taste preferences change over time according to species availability. Porcupine, guenon and blue duiker were all listed among the most abundant species in the forest and all ranked highly according to taste. When a type of meat becomes rare, people adapt and preferences eventually subside (Kümpel 2006). Chimpanzee, gorilla and drill were all absent from the taste rank.

Traditional beliefs are thought to have prevented the decline of primates in certain areas (Rose et al. 2003). The belief that humans transform into chimpanzees and gorillas appears to influence hunting habits. The risk of accidentally murdering a person in disguise, and the subsequent ill fates this may bring, sufficiently deterred many individuals from hunting apes (Etiendem 2008). However, 4 respondents had killed apes despite knowing about this traditional belief and those that spoke of the belief were in the minority. Modernisation, cultural integration and the decreasing availability of wildlife coupled with increasing demand for bushmeat have eroded many traditional belief systems (Barnett 2000). In Lebialem, belief in animal totems has especially declined among the younger generation (Etiendem 2008).

Determining the level of dependence on bushmeat by different sectors of society, and the nature of that dependence, was stated as a research priority in 2003 (Milner-Gulland et al. 2003). Studies conducted else- 
where in west and central Africa since then suggest that bushmeat is more important as a source of income in rural communities than as a source of protein (Democratic Republic of Congo [DRC]; de Merode et al. 2004), (Gabon; Starkey 2004), (Equatorial Guinea; Kümpel 2006). Bushmeat harvesters in Lebialem primarily stated economic reasons for involvement and appear to sell more bushmeat than they consume. However, the reasons given by respondents to justify their harvesting activities differed significantly between the 6 villages. Although income generation predominated in the Bangwa and M'muock communities, the Mundani of Bechati and Besali mainly specified dietary reasons for harvesting. The proportion of harvests sold and consumed suggests that Mundani still sell more than they eat but generally sell a lesser proportion than the Bangwa and M'muock.

The difference in the nature of reliance on bushmeat by different ethnic groups may be more circumstantial rather than a direct reflection of cultural difference. The Mundani communities are relatively remote and insular due to the nature of the topography in the region and the distance from Menji. Extremely poor roads over the mountainous landscape and impassable rivers during the wet season prevent public transport links connecting Wabane sub-division to the rest of Lebialem. Poor access to external markets may be the reason why the majority of harvesters in Bechati and Besali hunt primarily for subsistence, but sell their surplus catch to neighbours to supplement their income. A different scenario was reported by Willcox \& Nambu (2007), who found that commercial hunting was more prolific in areas with no road access, because these areas had no means of transporting heavy agricultural produce.

The general lack of paid employment in Lebialem still forces many to consider the bushmeat trade as one of the few financial options. Although the majority had other primary income-generating occupations, the need for additional cash appears to have persuaded individuals to adopt multiple enterprise lifestyles in order to earn money from a range of activities (Brown 2003). Trapping often played a minor role in respondents' economic diversification strategies, and this may be due to the difference in harvest composition between hunters and trappers. Trappers often obtain smaller prey with little economic value that is consumed rather than sold. With an average commitment of just $3 \mathrm{~d} \mathrm{wk}^{-1}$, harvesters are able to spend most of their time engaged with other activities, such as farming. The attraction and importance of harvesting as a complimentary income source is reflected in the flexibility of labour input and the nature of the economic returns.
Agriculture requires a large amount of temporal and monetary investment. Oil palm and cocoa, 2 of the principle cash crops in Lebialem, take several years to mature before harvesting can begin. Even with harvest regularity, income is seasonal and usually limited to 1 payment $\mathrm{yr}^{-1}$. The selling of bushmeat enables farmers to make smaller amounts of money throughout the year. As a tradable commodity, bushmeat has a high value to weight ratio, making transportation relatively easy, and once smoked it can be stored without expensive refrigeration (Brown \& Williams 2003). Bushmeat harvesting can be intensified between crop seasons, and for low levels of investment offers rapid returns (Solly 2004). It is therefore regarded as an instant safety-net in times of financial hardship and when unexpected expenses such as medical bills arise (Bowen-Jones et al. 2003). Solly (2007) found that the instant cash generated from bushmeat harvesting also played an important social role. Men in Cameroon are under pressure to display generosity in the social setting through buying alcohol. The 'quick, easy money' earned from bushmeat can legitimately be frittered away on such expenses.

Bushmeat is widely recognised as an important source of protein in the Congo Basin (Ntiamoa-Baidu 1997, Fa et al. 2003). It is usually the most available in rural communities and often the most preferred (Njiforti 1996, Schenck et al. 2006). On average in Cameroon, bushmeat supplies $26 \mathrm{~g}$ of daily protein intake per person, equivalent to half the recommended daily protein requirement (FAO/WHO/UNU 1985, Fa et al. 2003). Based on average weekly consumption estimates provided by interviewees rather than actual protein intake data, bushmeat appears to be the animal protein consumed most frequently by harvesters in Lebialem. This may be because even those that sell the majority of their catch remove and consume the internal organs before smoking the meat. However, fish was consumed on a regular basis by the majority of respondents and was the principle protein available in the communities (Etiendem 2008).

Brashares et al. (2004) noted a direct link between bushmeat demand and fish supply, suggesting that variations in fish supply drove bushmeat sales. Bushmeat consumption in Lebialem was negatively correlated with fish consumption. This could be indicative of a similar causal relationship but further investigation would be necessary to confirm this. Nevertheless, bushmeat and fish appear to be intrinsically linked as substitutes. Fish and bushmeat share more characteristics with one another than either do with domestic meat. Both are usually sold smoked rather than fresh and can be harvested locally at minimal expense. Fish is currently extracted using a fencing technique, however, which is reported to be depleting this resource 
(Etiendem 2008). Whether current harvests of bushmeat or fish can be sustained in the long term is questionable.

\section{CONCLUSIONS}

Harvester reliance on bushmeat appears to be mainly financial in Lebialem. Whilst bushmeat remains an important dietary component for hunters and trappers, fish was the principle source of animal protein consumed on a regular basis. The widespread use of shotguns is likely to have played a role in the perceived decline of wildlife, but the necessary increase in effort needed to maintain acceptable catch sizes is likely to increase harvester receptivity to alternatives. If financial reliance on bushmeat harvesting and the volume of species extracted is to be reduced, the development of economic alternatives should be given priority. These need to be flexible in terms of labour input, involve minimal financial investment and provide similar economic rates of return. In areas with poor access to external markets, alternative saleable products should be marketable locally or have a high value to weight ratio to justify long distance transportation. Research is now being conducted to identify appropriate economic alternatives, given the findings presented. Beekeeping is one option as it has similar characteristics to bushmeat harvesting in terms of earnings potential, market demand, land requirements and temporal investment. More than 130 hunters and trappers from Lebialem were trained in beekeeping in 2009 as part of a project established by J. H. W. The effectiveness of this and various other approaches are still being evaluated and a future paper is forthcoming.

To strengthen livelihood security and reduce the risk of food shortages in the future, fishing practices need to become more sustainable in Lebialem. Non-meat proteins should also be promoted through education about basic dietary requirements and the various sources of different nutrients. Efforts to improve agricultural productivity through sustainable means, i.e. permaculture and agroforestry, and assistance in adding value to existing produce will not only further increase food security but also lessen the financial burden on bushmeat harvesters. A basic understanding of financial management and access to microcredit and community savings schemes could also help prevent some of the financial hardships that force individuals to turn to hunting and trapping. Whilst the outlawing of bushmeat is undesirable from a livelihood perspective and impractical from an enforcement one, hunters must be dissuaded from killing threatened species through law enforcement and education emphasising the extinction risk and the economic need to reduce reliance on a depleting resource. These are all essential components of a multifaceted approach to bushmeat mitigation.

Acknowledgements. The authors thank K.A.I. Nekaris, S.K. Bearder, G. Donati and C.M. Hill for providing advice during the planning, data analysis and write-up stages. We thank M. MacLean for granting research ethics approval. For guidance and logistical support in the field we thank L. Nkembi, D. Lekeaka, S. Ajabji, R. Achah and F. Mbunya from the Environment and Rural Development Foundation (ERuDeF). We are particularly grateful to P. Tendem and P. Nkwetta who acted as research assistants and to all the hunters and trappers who participated in this study. This research was conducted by J.H.W. as part of an MSc in Primate Conservation at Oxford Brookes University and was supported by a Primate Society of Great Britain (PSGB) Conservation Grant.

\section{LITERATURE CITED}

Ajabji S, Tendem P (2008) A socio-economic report for the Bechati-Fossimondi-Besali forest adjacent villages. Environment and Rural Development Foundation, Buea

Barnes RFW (2002) The bushmeat boom and bust in West and Central Africa. Oryx 36:236-242

Barnett R (2000) Food for thought: the utilization of wild meat in eastern and southern Africa. Available at: www.traffic. org/general-topics/ (accessed January 2010)

Bennett EL (2002) Is there a link between wild meat and food security? Conserv Biol 16:590-592

Bennett EL, Robinson JG (2000) Hunting of wildlife in tropical forests: implications for biodiversity and forest peoples. The World Bank, Washington, DC

Bennett EL, Blencowe E, Brandon K, Brown D and others (2007) Hunting for consensus: reconciling bushmeat harvest, conservation, and development policy in West and Central Africa. Conserv Biol 21:884-887

Bergl RA, Oates JF, Fotso R (2007) Distribution and protected area coverage of endemic taxa in West Africa's Biafran forests and highlands. Biol Conserv 134:195-208

Bowen-Jones E, Pendry S (1999) The threat to primates and other mammals from the bushmeat trade in Africa, and how this threat could be diminished. Oryx 33:233-246

$>$ Bowen-Jones E, Brown D, Robinson EJZ (2003) Economic commodity or environmental crisis? An interdisciplinary approach to analysing the bushmeat trade in Central and West Africa. Area 35:390-402

Brashares JS, Arcese P, Sam MK, Coppolillo PB, Sinclair ARE, Balmford A (2004) Bushmeat hunting, wildlife declines and fish supply in West Africa. Science 306:1180-1183

Brown D (2003) Is the best the enemy of the good? Livelihood perspectives on bushmeat harvesting and trade - some issues and challenges. Available at: www.odi.org.uk/ccef/ projects/wildmeatproject.htm (accessed January 2009)

$>$ Brown D, Williams A (2003) The case for bushmeat as a component of development policy: issues and challenges. Int Forest Rev 5:148-155

CIA (2008) The world factbook: Cameroon. Available at www.cia.gov/library/publications/the-world-factbook/geos/ cm.html (accessed December 2008)

Coad L (2007) Bushmeat hunting in Gabon: socio-economics and hunter behaviour. PhD thesis, University of Cambridge and Imperial College London 
Cowlishaw G, Dunbar R (2000) Primate conservation biology. The University of Chicago Press, Chicago

Cowlishaw G, Mendelson S, Rowcliffe JM (2005a) Evidence for post-depletion sustainability in a mature bushmeat market. J Appl Ecol 42:460-468

Cowlishaw G, Mendelson S, Rowcliffe JM (2005b) Structure and operation of a bushmeat commodity chain in southwestern Ghana. Conserv Biol 19:139-149

de Merode E, Homewood K, Cowlishaw G (2004) The value of bushmeat and other wild foods to rural households living in extreme poverty in Democratic Republic of Congo. Biol Conserv 118:573-581

Dey I (1993) Qualitative data analysis: a user friendly guide for social scientists. Routledge, London

Djeukam R (2004) The wildlife law as a tool for protecting threatened species in Cameroon. Ministry of Environment and Forestry, Yaoundé

Ekinde A, Khumbah PA (2006) Cross River gorilla surveys in south east UFA 11-002 and search for genetic samples in the Besali-Bechati-Fossimondi forests. Wildlife Conservation Society, Limbe, and Environment and Rural Development Foundation, Buea

Etiendem DN (2008) Traditional knowledge on Cross River gorilla conservation: a case study in the Bechati-Fossimondi-Besali area, southwest Cameroon. MSc dissertation, Vrije Universiteit Brussel, Brussels

Eves HE, Ruggiero RG (2000) Socioeconomics and the sustainability of hunting in the forests of northern Congo (Brazzaville). In: Robinson JG, Bennett EL (eds) Hunting for sustainability in tropical forests. Columbia University Press, New York, p 427-454

Fa JE (2007) Bushmeat markets - white elephants or red herrings? In: Davies G, Brown D (eds) Bushmeat and livelihoods: wildlife management and poverty reduction. Blackwell Publishing, Oxford, p 47-60

Fa JE, Peres CA, Meeuwig J (2002) Bushmeat exploitation in tropical forests: an intercontinental comparison. Conserv Biol 16:232-237

Fa JE, Currie D, Meeuwig J (2003) Bushmeat and food security in the Congo Basin: linkages between wildlife and people's future. Environ Conserv 30:71-78

Fa JE, Ryan SF, Bell DJ (2005) Hunting vulnerability, ecological characteristics and harvest rates of bushmeat species in afrotropical forests. Biol Conserv 121:167-176

Fa JE, Seymour S, Dupain J, Amin R, Albrechtsen L, Macdonald D (2006) Getting to grips with the magnitude of exploitation: bushmeat in the Cross-Sanaga rivers region, Nigeria and Cameroon. Biol Conserv 129: $497-510$

FAO/WHO/UNU (1985) Energy and protein requirements. Available at: www.fao.org/DOCREP/003/AA040E/AA040E00. HTM (accessed February 2009)

Field A (2005) Discovering statistics using SPSS, 2nd edn. SAGE Publications, London

Forboseh PF, Eno-Nku M, Sunderland TCH (2007) Priority setting for conservation in south-west Cameroon based on large mammal surveys. Oryx 41:255-262

Gravetter FJ, Wallnau LB (2000) Statistics for the behavioral sciences, 5th edn. Wadsworth/Thomson Learning, Belmont

Institut National de la Statistique (2006) Annuaire Statistique $\mathrm{du}$ Cameroun 2006. Available at: www.statisticscameroon.org (accessed September 2007)

International Tropical Timber Organization (2006) Status of tropical forest management 2005. Technical Series No. 24. Available at: www.itto.or.jp/live/PageDisplayHandler? pageId=203 (accessed January 2009)
Isaac NJB, Cowlishaw G (2004) How species respond to multiple extinction threats. Proc R Soc Lond B Biol Sci 271: 1135-1141

IUCN (2009) IUCN Red List of threatened species. Version 2009.1. Available at: www.iucnredlist.org (accessed July 2009)

Kingdon J (1997) The Kingdon field guide to African mammals. Academic Press, London

Kümpel NF (2006) Incentives for sustainable hunting of bushmeat in Rio Muni. PhD thesis, Imperial College London

Lahm SA (1993) Ecology and economics of human/wildlife interaction in northeastern Gabon. PhD thesis, New York University

Maisels F, Keming E, Kemei M, Toh C (2001) The extirpation of large mammals and implications for montane forest conservation: the case of the Kilum-Ijim Forest, Northwest Province, Cameroon. Oryx 35:322-331

Mascia MB, Brosius JP, Dobson TA, Forbes BC, Horowitz L, McKean MA, Turner NJ (2003) Conservation and the social sciences. Conserv Biol 17:649-650

Mbaku JM (2005) Culture and customs of Cameroon. Greenwood Press, Westport, CT

Mendelson S, Cowlishaw G, Rowcliffe JM (2003) Anatomy of a bushmeat commodity chain in Takoradi, Ghana. J Peasant Stud 31:73-100

Milner-Gulland EJ, Bennett EL, and the SCB 2002 Annual Meeting Wild Meat Group (2003) Wild meat: the bigger picture. Trends Ecol Evol 18:351-357

> Muchaal PK, Ngandjui G (1999) Impact of village hunting on wildlife populations in the western Dja Reserve, Cameroon. Conserv Biol 13:385-396

Nasi R, Brown D, Wilkie D, Bennett E, Tutin C, van Tol G, Christophersen T (2008) Conservation and use of wildlifebased resources: the bushmeat crisis, Technical Series No. 33. Secretariat of the Convention on Biological Diversity, Montreal, and Center for International Forestry Research, Bogor

Nchanji AC (2005) Elephant-poaching weapons and new experiences from the Banyang-Mbo Wildlife Sanctuary, Cameroon. Pachyderm 39:33-42

Njiforti HL (1996) Preferences and present demand for bushmeat in north Cameroon: some implications for wildlife conservation. Environ Conserv 23:149-155

Nkembi L, Skeen R, Ndeloh D (2006) The Lebialem Highlands Montane Birds' Conservation Project, Cameroon. Environment and Rural Development Foundation, Buea

Ntiamoa-Baidu Y (1997) Wildlife and food security in Africa. Available at www.fao.org/docrep/W7540E/w7540e00.htm (accessed January 2009)

O'Reilly K (2005) Ethnographic methods. Routledge, London

Oates JF (1996) Habitat alteration, hunting and the conservation of folivorous primates in African forests. Aust J Ecol $21: 1-9$

Oates JF, Abedi-Lartey M, McGraw WS, Struhsaker TT, Whitesides GH (2000) Extinction of a West African red colobus monkey. Conserv Biol 14:1526-1532

Peres CA (2000) Effects of subsistence hunting on vertebrate community structure in Amazonian forests. Conserv Biol 14:240-253

Rietbergen-McCracken J, Narayan D (1998) Participation and social assessment: tools and techniques. The World Bank, Washington, DC

Robinson JG, Bennett EL (eds) (2000) Carrying capacity limits to sustainable hunting in tropical forests. In: Hunting for sustainability in tropical forests. Columbia University Press, New York, NY, p 13-30 
Robinson JG, Redford KH (1994) Measuring the sustainability of hunting in tropical forests. Oryx 28:249-256

Rose AL, Mittermeier RA, Langrand O, Ampadu-Agyei O, Butynski TM (2003) Consuming nature: a photo essay on African rain forest exploitation. Altisima Press, Palos Verdes, CA

Sanderson IT (1940) The mammals of the north Cameroons forest area. Trans Zool Soc Lond 24:623-725

Schenck M, Effa EN, Starkey M, Wilkie D and others (2006) Why people eat bushmeat: results from two-choice taste tests in Gabon, Central Africa. Hum Ecol 34:433-445

Solly H (2004) Bushmeat hunters and secondary traders: making the distinction for livelihood improvement. ODI Wildlife Policy Briefing 8. Available at: www.odi.org.uk/resources/ details.asp?id=2421\&title=bushmeat-hunters-secondarytraders-making-distinction-livelihood-improvement (accessed January 2009)

Solly H (2007) Cameroon: from free gift to valued commodity -the bushmeat commodity chain around the Dja Reserve.
In: Davies G, Brown D (eds) Bushmeat and livelihoods: wildlife management and poverty reduction. Blackwell Publishing, Oxford, p 61-72

Starkey M (2004) Commerce and subsistence: the hunting, consumption and sale of bushmeat in Gabon. PhD thesis, University of Cambridge

van Vliet N, Nasi R (2008) Hunting for livelihood in northeast Gabon: patterns, evolution, and sustainability. Ecol Soc 13:33. Available at www.ecologyandsociety.org/vol13/ iss2/art33/ (accessed January 2009)

- Waltert M, Lien, Faber K, Mühlenberg M (2002) Further declines of threatened primates in the Korup project area, southwest Cameroon. Oryx 36:257-265

Wilkie DS, Carpenter JF (1999) Bushmeat hunting in the Congo Basin: an assessment of impacts and options for mitigation. Biodivers Conserv 8:927-955

Willcox AS, Nambu DM (2007) Wildlife hunting practices and bushmeat dynamics of the Banyangi and Mbo people of southwestern Cameroon. Biol Conserv 134:251-261

Appendix 1. Semi-structured interview questions

Reasons for harvesting bushmeat
1. How many years have you hunted/trapped?
2. Why did you become a hunter/trapper?
Harvesting behaviour
3. What is your method of hunting/trapping?
4. How much do your hunting/trapping materials cost?
5. How many traps do you set per year?
6. How many days per week or per month do you hunt/trap?
7. How many hours or days do you spend in the forest on each trip?
8. Do you hunt more in some months than in others?
9. How many hours does it take you to trek to the forest?
10. Which forest do you hunt in?
Harvest composition
11. What animals do you hunt/trap?
12. Why do you hunt/trap those animals?
13. How much do you sell these animals for?
14. Do you or have you ever killed a chimpanzee or a gorilla?
15. What determines the price?
16. Which bushmeat species are the tastiest? (top 5 in order of preference)
17. How many animals can you catch per trip?
18. Have you noticed a change in how easy it is to catch animals now compared to
when you started hunting/trapping?
19. Have certain animals become harder to catch?
20. Are there any traditional laws or beliefs regarding animals?
Income sources
21. What are your occupations? (list in order of income)
22. What alternatives to hunting/trapping would you consider?
Diet
23. How many animals do you sell and how many do you eat per week?
24. What other forms of meat do you eat?
25. How many days per week do you eat fish?
26. How many days per week do you eat domestic meat?
27. How many days per week do you eat bushmeat?

Editorial responsibility: Anna Nekaris, Oxford, UK
Submitted: February 16, 2009; Accepted: October 5, 2009

Proofs received from author(s): January 27, 2010 